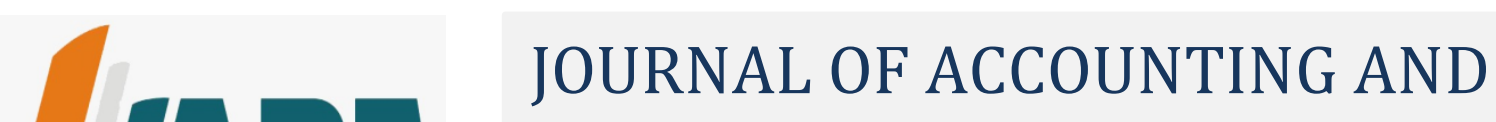 BUSINESS EDUCATION \\ P-ISSN 2528-7281 E-ISSN 2528-729X \\ E-mail: jabe.journal@um.ac.id
}

\section{The Analysis of Computer Based Test (CBT) Implementation: A Phenomenological Study}

\author{
Sofiyatul Fitriyah \\ Nujmatul Laily \\ Universitas Negeri Malang \\ sofia.fitryah@gmail.com
}

\begin{abstract}
The purpose of this research is to describe the planning, implementation, and obstacles in implementing CBT. It is a qualitative research using phenomenological approach. The subjects of this research are Accounting teachers and students in Vocational High School 1 Turen. The method for collecting the data are interview and documentation. The validation of data was conducted by the triangulation of sources. Data analysis using Miles and Huberman technic. The research shows that (1) Planning Computer Based Test (CBT) for midterm and final test includes the formulation of objectives, selecting officers, preparing the system, facilities, and infrastructures needed for the test, socialization for teachers and students, preparing the test items and CBT simulation. (2) The implementation of the computer-based test (CBT) for midterm and final test is the responsibility of Proctor and technician. Teachers' role during the CBT only as the supervisor of the test and assess the result. (3) Problems in the implementation of CBT are the trouble of internet connection, electricity, and the chance for the student to browse easily. There are some strategies to overcome those problems such as giving a clear instruction as the supervisor of CBT, preparing enough genset, empowering wifi connection and server for the stability of internet connection.
\end{abstract}

Keywords: computer-based test, technology acceptance model

\section{INTRODUCTION}

Teachers' success in teaching is the key to success in school education which can be seen by an evaluation. It is in line with Dimyati \& Mudjiono (2009: 189) says that a teacher should conduct an evaluation to provide the information about the strength and weakness of the learning process and outcome. Teachers may conduct the evaluation by test or non-test. In the test method, teachers conduct a written text to measure or assess students' understanding of the lesson. In the non-test method, teachers assess students' affective norms through observing students attitude during the learning process. Teachers conduct the evaluation in some certain times based on the lesson plan. 
In conducting the evaluation, teachers should obey the current curriculum, which is 2013 curriculum. Based on the curriculum, teachers should do the evaluation by using authentic assessment. Based on the Regulation of the Minister of Education and Culture 1042014 about Learning Assessment, authentic assessment is an assessment that expects learners to perform attitude, apply the knowledge and skills from the learning process in real life. In this assessment, teachers evaluate by measuring the knowledge, attitude, and skills based on the process and outcome of the learning process. Besides, students are also expected to apply the theory or concept in the learning process to real life.

Schools conduct a routine evaluation each semester in the form of midterm and final test. It is aimed to measure the improvement of students' skills and knowledge toward the lessons in one semester. In other words, students' knowledge is assessed through those tests. Based on the regulation of the Minister of Education and Culture 532015 about Learning Outcome Assessment by Teachers and Schools in Elementary and Secondary Level, the assessment on students' knowledge should be conducted through a written and oral test. Generally, schools conduct these evaluations in the form of a paper best test (PBT) which using pencil or pen as the media. PBT has some weaknesses in the implementation such as (1) spends a huge money, (2) needs a lot of papers, (3) tends to be bocor and broken, (4) needs a lot of time and effort to score, (5) could not announce the result as soon as possible, and (6) students easily cheat during the test.

Vocational High School begins to overcome the problems of PBT by implementing CBT for midterm and final test. CBT is a test using the computer as the media. This transition is aimed to minimize the weaknesses in PBT test, paperless, habituate students for a computer-based test, cut the spending, improve students' skills in using technology especially computer, increase students' honesty, and introduce students to the advancement of technology in terms of information and communication in education scope. This transition is strengthened by a research conducted by Nugroho (2009) shows that online test has some benefits such as cost-effective in conducting a test, time-effective, direct test result, and students' independent in doing the test. Research conducted by Bodmann \& Robinson (2004) also shows that students could finish the computer-based test faster than the paper-based test with the same score. Jimoh (2012) also stated that most of the students are competent in using the computer for the CBT. 
A study by Permatasari (2014) shows that in CBT, students can know the test result directly after finishing the test. The result of the test will automatically be uploaded to the teachers' account and students with the score under the minimum standard will be directly known. Nurhidayat (2016) also stated that after finishing the national examination in the computer-based test, schools can directly upload students' answer sheet to the central government. It makes the process of sending students' answer sheet can be done easily, fast, and secure without damaging the answers sheet. Based on those findings, it can be concluded that CBT has a number of benefits.

There are a lot of research has been conducted about CBT, but it tends to focus on testing the hypothesis only. There is only a few qualitative research that deeply investigates the CBT. That is why this research is conducted for a deeper analysis about the transition of PBT into CBT in terms of planning, implementing, and problems occurred. TAM theory is used as the ground of theory for this research. TAM is a theory discuss receiving technology from the perspective of human as users. It has two beliefs which are the perception of usability and the perception of the easiness as the main factor of perceiving computer attitude. Those two factors show that the perception of technology users determine the attitude in using the technology. Based on this theory, this research investigates the transition from PBT to CBT based on teachers' and students perception as users.

SMKN 1 Turen is one of the schools that has already implemented CBT for midterm and final test. The implementation of CBT is something new for this school in the midterm and final test. Based on the observation has been conducted, still, there are some problems in the implementation of CBT in SMKN 1 Turen such as the trouble of the internet connection where students' PCs and laptops could not connect wifi and internet. It makes students could not do the test maximally because the time is limited due to the problems occurred. Moreover, based on the interview with accounting students, they got some problems in doing the test such as the incomplete test items and the problem of internet connection. These things disturb students' concentration in doing the test. Based on the interview with accounting teachers, students can easily browse the internet to find the answers. It caused the result of the test cannot really measure students' competence. Based on the explanation above, the implementation of CBT in SMKN 1 Turen will be deeply investigated in this research. 


\section{LITERATURE REVIEW AND HYPOTHESES}

\section{Theory of Technology Acceptance Model (TAM)}

Technology Acceptance Model (TAM) is one of the models that is built to analyze and understand factors that influence the acceptance of using computer technology that was introduced by Fred Davis in 1985. TAM is one of theory discusses the acceptance of technology in the perspective of human as the user. TAM goal is to explain and predict the users' acceptance of a system of information. TAM provides a theoretical basis to know the factors that influence the acceptance of organization toward a technology. TAM is visualized as a model below.

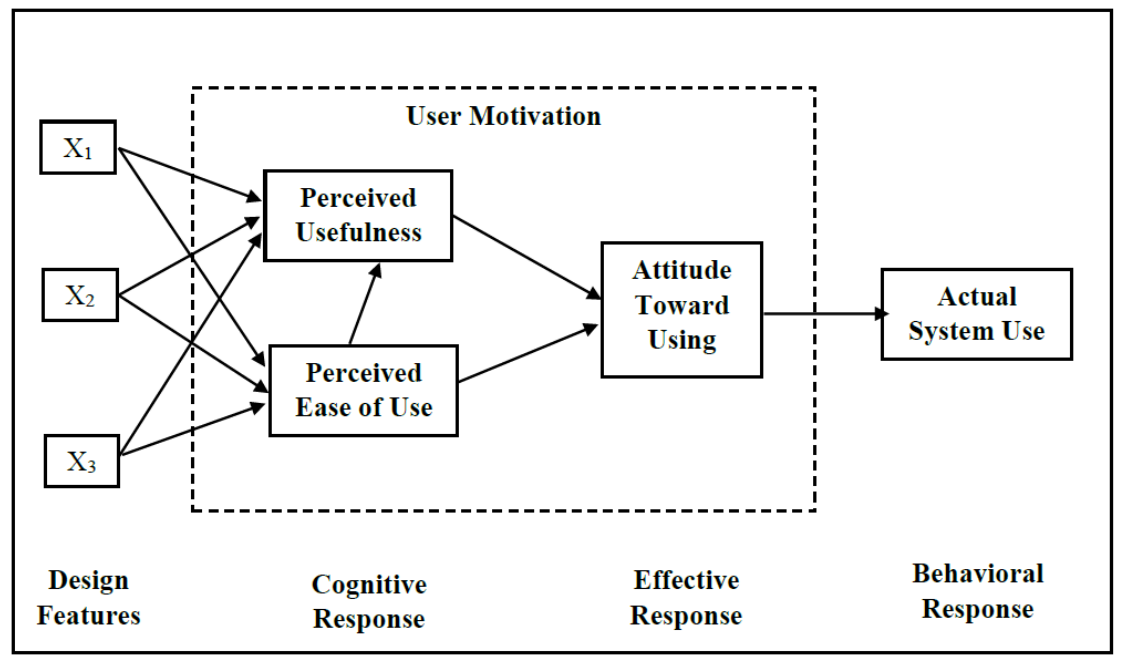

Figure 1. Technology Acceptance Model (Davis, 1985)

TAM model is developed from the theory of psychology, explain about the attitude of the computer user based on belief, attitude, intention, and user behavior relationship. TAM puts two beliefs, which are the perception of usability and the perception of easiness to use as the main factor of computer acceptance attitude. Both of those factors show that the perception of technology users determines the attitude in using the technology.

David (1989) states that the definition of usability perception comes from the word "useful" which mean can be used and benefitting. The perception of usability focus on how far someone believes that by using a certain system will improve their productivity in working. If it is applied in the computer-based test, so this usability perception is a measurement where the use of a computer for examination can improve the skills and students' achievement.

Tarigan (2010) states the perception of users toward the benefit of technology can be measured by some factors such as improving users' productivity and efficiency. Davis (1989) states that the perception of easiness in using the technology focus on how far someone believes 
that using a system does not need too much effort. The definition of this perception follows the definition of the word "ease" that means free from difficulties. In the application of the computer-based test, it is a measurement of how learners are able to operate the computer to finish the test easily.

TAM believes that the perception of usability and easiness of using technology felt by users can predict their attitude toward the technology that can predict the users' acceptance of the technology. That is why those perceptions are used in this research as the basis to know teachers' and students' perception of the computer-based test. Their perception can give information about the acceptance of computer users as a media in the test and the success of computer-based test in learning evaluation.

\section{Computer Based Test (CBT)}

The computer-based test is a test using a computer as the media. The computer-based test is conducted in a computer laboratory connected with the internet connection (Suryanto, 2016). In the test, each student sits in front of one unit of a computer connected to the internet connection. Multiple choices are usually used as the test items in the computer-based test but do not limit to other forms of the test. Even if usually it is conducted in a computer laboratory with the internet connection, but it is also possible to conduct the computer-based test in a classroom using laptops or PCs connected with the internet connection.

\section{METHODS}

The phenomenological approach is used in this qualitative research. The phenomenological approach is a research strategy where human's experience on certain phenomena is being identified. The source of data in this research was based on the interview with teachers and students in accounting class. The key source in this research was accounting teacher in SMKN 1 Turen. This informant was expected to give information related to the implementation of CBT. The other sources were accounting students in XII grade that are adjusted to the needs of data.

The model of Miles and Huberman (1994) is used to analyze the data. Miles and Huberman (in Sugiyono, 2010: 246) states that the analysis of qualitative data is conducted interactively and continually until it is finished and the data was expired. The steps to analyze the data are data collection, data reduction, data display, and conclusion drawing/verification. 


\section{RESULTS}

\section{Planning Computer Based Test (CBT) for Midterm and Final Test in SMKN 1 Turen}

There is some planning before the implementation of CBT at school. This planning included the identification of objectives, selection of CBT officers, preparation of examination system, preparation of supporting facilities, socialization, the preparation of the test items, and simulation or try out. The background of CBT implementation for midterm and final test was for the effective use of paper. In addition, CBT was aimed to maximize the use of technology to introduce to students that an examination can be conducted manually, using school's facilities in a good manner, budget and effort efficiency.

The school planned a special team which in charge to manage and controls to the CBT, consisted of Proctor and technician. Proctor is in charge to control the system and networking used in the CBT. The technician is responsible for the computer used in the CBT. Only teachers and staffs with skill and competence of technology and networking assigned the members of that special team. Proctor and technician act as the committee managing the preparation of CBT such as budget allocation, system, infrastructure, and internet networking for the implementation of CBT. Teachers do not involve in those things.

Before implementing CBT, the school's committee give a socialization for teachers and students about the implementation of CBT. Teachers will be informed about the right supervision for the computer-based test, while students are informed about the instruction of doing the computer-based test. Teachers' role in CBT is to prepare the test items and the answer key. Before conducting the CBT, the committee held a simulation so students can understand the mechanism and avoid difficulties that might occur during the test.

\section{Implementation of Computer Based Test (CBT) for midterm and final test at SMKN 1 Turen}

During the CBT, the proctor was controlling the system for all of the test rooms and inform the password to access the test. In addition, the technician also should always ready to solve problems related to students' computer. During the test, teachers were responsible as a supervisor for the test. The procedure of CBT is not different with the procedure of PBT. In CBT, teachers' job was decreasing such as checking students' answer. As a supervisor of CBT, teachers only needed to check the attendance and the examination official report. 
After the test finished, the system would automatically check students' answer so teachers can directly get students' answer. The score would be still processed by the teacher. Teachers could help students which the score is under the minimum of the standard by giving addition assignment or remedial. Then, the teacher input students' remedial online. All students' score must be uploaded online using the provided software because students' report will be served online. It easier students because they can get their report at home online.

\section{Problems in the Implementation of Computer Based Test in SMKN 1 Turen}

There were some problems in the computer-based test such as students can easily browse for the answer on the internet, the test's result is invalid due to the mistakes in inputting the test items and answer key, unstable internet connection, and electricity as the main factors of problems in CBT.

Based on teachers' and students' opinion, there are some alternatives to solve those problems such as by giving a right guidance for supervisor teachers of CBT, creating more various test items, preparing enough genset, more careful in checking and inputting test items and answer key, strengthen the wifi signal, and the stability of internet connection.

\section{DISCUSSION}

\section{Planning Computer Based Test (CBT) for Midterm and Final Test in SMKN 1 Turen}

SMKN 1 Turen is one of the schools that already implement CBT for midterm and final test. This school planned the CBT including the formulation of goals, selection of the CBT officers, preparation of the system, facilities and infrastructure, socialization for teachers and students, preparation of test items, and the simulation or try out of CBT. The background and the goal in implementing CBT for midterm and final test in SMKN 1 Turen were to maximally use the advancement of technology in education, facilities provided by the school, introduce students that the examination can be conducted online using the computer, budget efficiency, and effort to conduct the test.

There were officers that controlled and managed the planning of CBT, they are the proctor and the technician which also in charge as the committee of the test. Only teachers and staffs with skill in terms of technology and networking that became the member of Proctor and technician. Nurhidayat (2016) states that the proctor should have background knowledge or skills 
in the technology of information and networking. The technician was assigned to prepare the infrastructure needed in the CBT such as computer, wifi or internet connection, the source of electricity, and other things related to CBT. The proctor was assigned to prepare the system of CBT, make sure the stability of internet connection and computer condition, mix and input the test items and answer key into the CBT system.

Socialization is conducted by educating individuals about the culture that should be followed in order to create a good society (Nasution, 2010: 126). Based on this theory, the socialization of CBT was conducted to introduce and guide teachers and students about the CBT. The test items and answer key are still the responsibility of teachers. Teachers' role is as the evaluator that the function is to know the success of teachers in the learning process (Noviani, 2012). Teachers must create test items and answer key for the test that would be given toward the proctor to be mixed and uploaded into the system of CBT.

A simulation or try out was held by the school before the CBT to inform students the steps of doing the test and make sure that the system, internet connection, and computers were in the best condition to be used. It is suitable with the Regulation of BNSP 0032/P/BNSP/III/2015 about the Technical Guideline of National Examination using Computer Based Test Academic Year 2014/2015 that in the try out, Proctor should check and make sure that all of the local servers are connected with internet, check all computers to be able to access the local server, and make sure that all systems in CBT already well functioned and in an active use.

\section{The Implementation of Computer Based Test (CBT) for Midterm and Final Test in SMKN 1 Turen}

The computer-based test is an examination system using a computer as the media. In this system, teachers do not directly involve in the process of CBT. Teachers only in charge as the supervisor of the test in CBT by filling the attendance and official report of the test. Teachers did not respond to the incomplete of the test items. All of the things during the CBT become the responsibility of Proctor and the technician.

The Proctor and technician were responsible to make sure that the test runs well. The proctor activated all of the CBT systems and make sure that the internet connection for all of the students' computer well connected. In addition, the technician was in charge to help the proctor to supervise the process of the test. It is in line with the Regulation of BNSP 
0032/P/BNSP/III/2015 about the Technical Guideline for National Examination with Computer Based Test Academic Year 2014/2015 that the role of the technician is to help and make sure the stability of LAN networking to be well functioned and solve as soon as possible for the technical problems. When problems occurred during the test, Proctor and technician should as soon as possible solve those problems so the test can run well.

Based on the observation, students operated the software and input a password to do the test. Students did the test by directly clicked the answers on the computer. During the test, teachers were in charge to supervise students in doing the test. The CBT system would directly check students' answer sheet after the test finished, so teachers could directly get students' score. Permatasari (2004) also states that in an online test, students' score will be automatically sent to the teacher's account, so teachers can do the further action toward students' score.

Each subject teacher is still responsible to process students' score. The data processing was conducted by uploading all of the students' score into the software provided. The system will automatically process students' score and present the score in the students' report. It because students' report already provided online. Students and parents could see the online report at home.

\section{Problems during the Computer Based Test (CBT) in SMKN 1 Turen}

Still, there were some problems in the implementation of CBT in SMKN 1 Turen. Based on the result of observation, the unstable of internet connection and electricity became the main problems during the CBT. Nurhidayat (2016) also states that unstable electricity is one of the problems in the process of CBT. Moreover, students could find or browse for the answer on the internet easily and the mistakes in inputting the test items and answer key make the result of students' result less valid.

There is some efforts done by school in solving those problems such as giving the right instruction toward the teacher as the supervisor of CBT, making the test items vary, preparing enough genset to anticipate the electricity problems, the proctor more carefully in mixing and inputting the test items and answer key, strengthen wifi signal and server for the stability of internet connection.

\section{CONCLUSION}


The planning of computer-based test (CBT) in SMKN 1 Turen including the formulation of goals, selection of CBT officers, preparation of systems, facilities and infrastructures, socialization for teachers and students, preparation of test items, and simulation or try out of CBT. The implementation of the computer-based test (CBT) for midterm and final test in SMKN 1 Turen has conducted by the proctor and technician. Teachers' role during the CBT only under the supervision of the test.

Problems in the implementation of CBT are the trouble of internet connection, electricity, and students' chance to browse for the answer easily on the internet. There are some efforts have been done by the school to solve those problems such as by giving the right guidelines for teachers in supervising the CBT, making variations in the test items, preparing enough genset, strengthen wifi signal and server for the stability of internet connection.

\section{REFERENCES}

Bodmann, Shawn M. \& Robinson, Daniel H. 2004. Speed and Performance Differences Among Computer-Based and Paper-Pencil Tests. Journal Educational Computing Research, 31 (1): 51.

Dimyati \& Mudjiono. 2009. Belajar dan Pembelajaran. Jakarta: Rineka Cipta.

Nasution. 2010. Sosiologi Pendidikan. Jakarta: Bumi Aksara.

Noviani, Shanti Astri. 2012. Pentingnya Evaluasi Pembelajaran dalam Proses Belajar Mengajar, (Online), (http://shantinoviani92.blogspot.com/2012/03/pentingnya-evaluasipembelajaran-dalam.html), diakses 7 Juni 2017.

Nugroho, Djarot. 2009. Ujia Online pada Mata Pelajaran Produktif. Jurnal Penelitian INFOKAM, 5 (1): 26-25.

Nurhidayat, Arif. 2016. Implementasi Ujian Nasional Berbasis Komputer atau Computer Based Test (CBT) di SMA N 1 Wonosari. Jurnal Administrasi Pendidikan, 2016 (2): 8-12.

Peraturan Badan Standart Nasional Pendidikan Nomor 0032/P/BNSP/III/2015 tentang Petunjuk Teknis Pelaksanaan Ujian Nasional Berbasis Komputer/Computer Based Test (UN CBT) Tahun Pelajaran 2014/2015.

Peraturan Menteri Pendidikan dan Kebudayaan Nomor 104 Tahun 2014 tentang Penilaian Hasil Belajar oleh Pendidik pada Pendidikan Dasar dan Pendidikan Menengah.

Permatasari, Arvynda. 2014. Pengelolaan Evaluasi Hasil Belajar Peserta Didik secara Online. Jurnal Ilmu Pendidikan, 24 (3): 261-264.

Putra, Nusa. 2012. Metode Penelitian Kualitatif Pendidikan. Jakarta: Rajawali Pers.

Sugiyono. 2010. Metode Penelitian Kuantitatif, Kualitatif dan $R$ \& D. Bandung: Penerbit Alfabeta. 